\title{
The Survival of Pinus ponderosa Saplings Subjected to Increasing Levels of Fire Behavior and Impacts on Post-Fire Growth
}

\author{
Wade D. Steady ${ }^{1,+}$, Raquel Partelli Feltrin ${ }^{1,+}$, Daniel M. Johnson ${ }^{2}{ }^{\circ}$, Aaron M. Sparks ${ }^{1}{ }^{(\mathbb{D}}$, \\ Crystal A. Kolden ${ }^{1}{ }^{(0}$, Alan F. Talhelm ${ }^{1}$, James A. Lutz ${ }^{3}{ }^{\circledR}$, Luigi Boschetti ${ }^{1}$, \\ Andrew T. Hudak ${ }^{4}$ (D), Andrew S. Nelson ${ }^{1}$ (D) and Alistair M. S. Smith ${ }^{1, *(D)}$ \\ 1 College of Natural Resources, University of Idaho, Moscow, ID 83844, USA; \\ stea0462@vandals.uidaho.edu (W.D.S.); part8527@vandals.uidaho.edu (R.P.F.); \\ asparks@uidaho.edu (A.M.S.); ckolden@uidaho.edu (C.A.K.); atalhelm@gmail.com (A.F.T.); \\ luigi@uidaho.edu (L.B.); asnelson@uidaho.edu (A.S.N.) \\ 2 Warnell School of Forestry and Natural Resources, University of Georgia, Athens, GA 30602, USA; \\ danjohnson@uga.edu \\ 3 S. J. \& Jessie E. Quinney College of Natural Resources, Utah State University, Logan, UT 84322-5230, USA; \\ james.lutz@usu.edu \\ 4 Rocky Mountain Research Station, USDA Forest Service, Moscow, ID 83843, USA; ahudak@fs.fed.us \\ * Correspondence: alistair@uidaho.edu \\ + Those authors contributed equally to this paper.
}

Received: 19 April 2019; Accepted: 7 May 2019; Published: 9 May 2019

\begin{abstract}
Improved predictions of tree species mortality and growth metrics following fires are important to assess fire impacts on forest succession, and ultimately forest growth and yield. Recent studies have shown that North American conifers exhibit a 'toxicological dose-response' relationship between fire behavior and the resultant mortality or recovery of the trees. Prior studies have not been conclusive due to potential pseudo-replication in the experimental design and time-limited observations. We explored whether dose-response relationships are observed in ponderosa pine (Pinus ponderosa) saplings exposed to surface fires of increasing fire behavior (as quantified by Fire Radiative Energy-FRE). We confirmed equivalent dose-response relationships to the prior studies that were focused on other conifer species. The post-fire growth in the saplings that survived the fires decreased with increasing FRE dosages, while the percentage mortality in the sapling dosage groups increased with the amount of FRE applied. Furthermore, as with lodgepole pine (Pinus contorta), a low FRE dosage could be applied that did not yield mortality in any of the replicates $(r=10)$. These results suggest that land management agencies could use planned burns to reduce fire hazard while still maintaining a crop of young saplings. Incorporation of these results into earth-system models and growth and yield models could help reduce uncertainties associated with the impacts of fire on timber growth, forest resilience, carbon dynamics, and ecosystem economics.
\end{abstract}

Keywords: fire severity; growth; yield; succession

\section{Introduction}

Globally, land management professionals are faced with increasing challenges of how to manage woodlands and forests in the face of larger and more destructive wildfires, while also increasing the use of planned fires as a pre-emptive mitigation approach [1,2]. Planned (or prescribed) fires are an important management tool in many fire-prone ecosystems; they can remove brush and unwanted plants [3] and help reduce fuel buildups that otherwise increase extreme wildfire and crown fire 
hazards. However, a challenge in using planned fires is determining what thresholds of different fire behavior characteristics (intensity, heat release, residence time, etc.) will yield the desired levels of mortality for various species/size classes [4,5]. If desirable trees die from planned fires or wildfires, land managers must either allocate and invest more time, money, and resources to replanting and replacing them, or forgo having those species in that location for the rotation of that stand. If the desirable trees survive but are damaged, any reductions in vigor or growth could impact carbon stocks and timber yield for that area [6]. This could delay harvests or reduce the volume expected, resulting in a potentially lower profit margin.

Several recent studies have sought to address these challenges through controlled laboratory burns and planned landscape fire experiments where saplings to mature trees (2.5-40 years) have been exposed to surface fires at varying fire behavior levels and the associated mortality or recovery documented [3,4,7-12]. Many of these studies have sought to shift post-hoc fire-severity research that is often associated with variants of the differenced normalized burn index (dNBR), which has been criticized for being too qualitative and lacking connections to post-fire plant physiology [13-20], into a quantitative and mechanistic paradigm by exposing plants to known amounts of heat and measuring the associated physiological responses $[7,21]$. As with the considerable fire effects research that has evaluated the direct and indirect impacts of fire behavior on stem and crown injury [22-29], this line of research has the considerable potential to revolutionize the development of models to assess post-fire effects $[5,7,21]$. These studies showed that the response of several North American conifer species exhibits toxicological dose-response relationships to fire, where increasing fire behavior as characterized by fire radiative energy (FRE) and flame lengths incident on the plants (the "doses") results in increased probability of mortality and increased growth retardation (the "responses") in the surviving saplings and trees [3,4,7-11,22]. Research has demonstrated that these relationships persist at large spatial and temporal scales, but that forest composition and pre-fire droughts produce complex interactions $[10,11]$.

A potential limitation of many of these studies is that plants are usually burned in groups, partly due to the nature of planned landscape fires. However, such an experimental design may lead to pseudo-replication errors and also may produce spurious results due to extra heat incident upon target plants due to neighboring plants igniting and burning. Equally, some plants could shield others from radiation, resulting in some plants receiving less heat. A second limitation of prior studies is that limited species at young size classes ( $<1 \mathrm{~m}$ height, $<5 \mathrm{~cm}$ diameter) have been investigated $[3,4,23]$, with the majority of research focused on mature trees [5,24-28]. Accurate information on how such young trees survive fires of different fire radiative energy dosages (and equivalent fire behavior metrics) could provide land managers with quantitative information on the degree of replanting that may be required following fires, or the degree of fire behavior needed to kill unwanted species. This is particularly apparent given past studies have demonstrated variable probabilities of survival for young saplings exposed to fire radiative energy dosages associated with low intensity surface fires [4]. For example, Pinus contorta saplings $(\mathrm{r}=7,[4])$ exposed to a dosage of $0.4 \mathrm{MJ} \mathrm{m}^{-2}$ exhibited $0 \%$ mortality, suggesting that Pinus contorta saplings may be able to wholly survive such low intensity fires. However, past assessments of Larix occidentalis mortality at dosages of $0.4 \mathrm{MJ} \mathrm{m}^{-2}$ have varied. In one study, well-watered Larix occidentalis saplings $(r=7,[8])$ exhibited 33\% mortality, while another ( $r=7,[11]$ ) observed $0 \%$ mortality. In addition, drought stress has been shown to have a complex relationship with Larix occidentalis mortality at $0.4 \mathrm{MJ} \mathrm{m}^{-2}$, with severely stressed saplings whose foliage had senesced before exposure to fire exhibiting $14 \%$ mortality and moderately stressed saplings whose foliage had not senesced exhibiting 43\% mortality $(r=7,[11])$.

In the current study, we assess whether dose-response relationships between FRE incident on the plant and the plant mortality (and recovery) are apparent for Pinus ponderosa (ponderosa pine, Pinus ponderosa Lawson \& C. Lawson var. ponderosa C. Lawson) saplings burned in individual experimental laboratory fires. Prior studies, under laboratory conditions, have evaluated two conifer species that commonly co-exist with Pinus ponderosa: Pinus contorta (lodgepole pine) and Larix occidentalis 
(western larch) [4], whereas mature Pinus ponderosa have been evaluated in landscape-scale planned fires $[9,26,29]$. However, only limited studies have evaluated young Pinus ponderosa saplings at landscape scales, $[3,12]$ and none to our knowledge, during controlled laboratory experiments.

As such, this paper seeks to test the following hypotheses:

(1) H1: Increased FRE (dose) results in increased mortality (response) in Pinus ponderosa saplings up to several months post-fire.

(2) H2: Increased FRE (dose) leads to decreased rate of growth (height and stem diameter) (response) of surviving Pinus ponderosa saplings up to several months post-fire.

(3) H3: The dose-response relationships observed for Pinus ponderosa saplings are comparable to those observed for Pinus contorta [4].

(4) H4: As hypothesized by [4], the dose-response relationships observed for Pinus ponderosa saplings during laboratory fires will exhibit a higher probability of mortality at lower dose levels as compared to similar age/size saplings burned during field experiments.

\section{Materials and Methods}

\subsection{Trees}

A total of 50 Pinus ponderosa saplings were grown in a greenhouse at the University of Idaho's Pitkin Nursery Center for Forest Nursery and Seedling Research, located in Moscow, ID. The overall growing methodology from seed to the experimental age/size followed prior studies $[4,8,30]$. The saplings were grown in $\sim 2.8 \mathrm{~L}$ pots for 2.5 years under natural light conditions and then subjected to surface fire in a combustion trial in a controlled laboratory setting. Following the combustion trials, they were maintained at the nursery (watered, fertilized, etc.) and evaluated until they entered dormancy, which was at approximately 4 months after the fire. Immediately prior to the combustion trials, the saplings averaged a height of $76.6 \mathrm{~cm}($ S.E. $=2.1 \mathrm{~cm})$ and a diameter at root collar of $0.54 \mathrm{~cm}($ S.E. $=0.01 \mathrm{~cm})$.

\subsection{Experimental Design and Fire Experiments}

The experiment was a randomized design; saplings were re-arranged each week to provide equal exposure to sunlight, water, and other environmental factors. All saplings were kept at the greenhouse until the experimental burns were conducted in June 2018. The saplings were watered to field capacity $24 \mathrm{~h}$ prior to being burned. The combustion trials were conducted at the Idaho Fire Initiative for Research and Education (IFIRE) laboratory, a climatically controlled indoor environment adjacent to the Forest Nursery site where the saplings were grown and maintained.

Following $[4,11]$ the specific dosages of FRE were created by combusting dry ( $0 \%$ moisture content) fuel beds of pure western white pine (Pinus monticola) needles that had been thermally characterized through bomb calorimetry and assessed in prior experiments to have consistent rate of fire spread, combustion completeness, and radiant energy release by mass $[4,11,31]$. The Pinus monticola needles were kept in the oven until immediately prior to each combustion experiment to minimize gains in moisture content. Based on previous studies we can create defined FRE dosages from a known fuel load of western white pine needles [4,7]. Specifically, as described in [4,7], we used the following regression, which has been shown to have an error of $\pm 6 \%$, between FRE dosage (MJ) and the pre-fire fuel load $(\mathrm{kg})$ : FRE dosage $=2.679 \times$ pre-fire fuel load to create the specific dosages of FRE.

The needles were prepared by sorting them to remove impurities such as bark, moss, or leaves and then oven-drying them for $48 \mathrm{~h}$ at $\sim 100{ }^{\circ} \mathrm{C}$ to ensure minimal fuel moisture content [32]. The needles were then distributed evenly across circular $1 \mathrm{~m}^{2}$ beds. A uniform flaming front was achieved by igniting $\sim 2 \mathrm{~g}$ of ethanol with a filament wire situated at the edge of the bed. This remote ignition apparatus allows each experimental run to begin without people being present in the combustion chamber, thereby minimizing air movement associated with the opening and shutting of doors. Two video cameras recorded each experimental burn, enabling maximum flame length to be measured (Figure 1). 
START (1)
MIDDLE

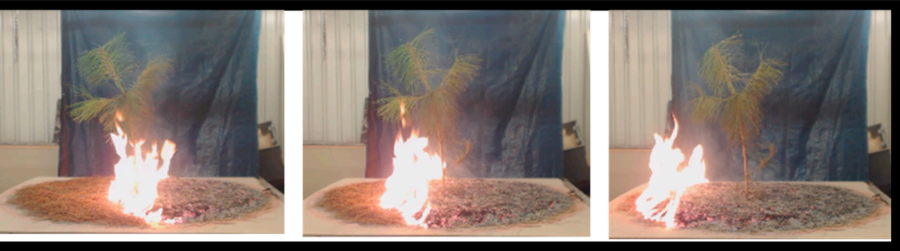

FRE $=0.8 \mathrm{MJ} \mathrm{m}^{-2}$

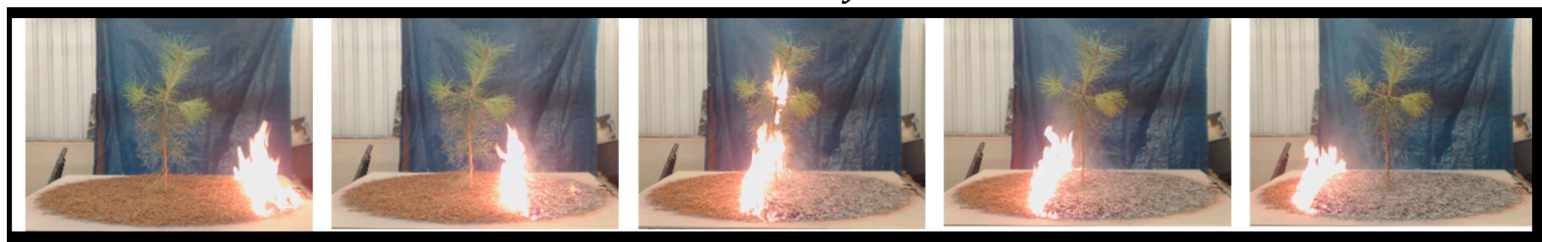

FRE $=0.6 \mathrm{MJ} \mathrm{m} \mathrm{m}^{-2}$

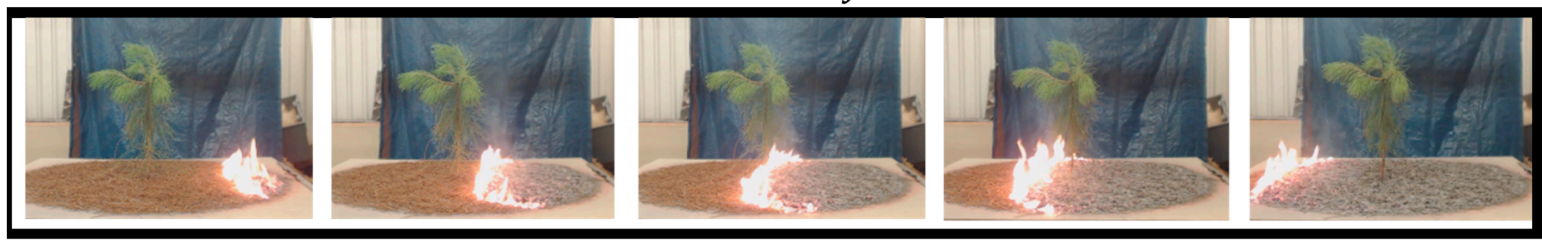

FRE $=0.4 \mathrm{MJ} \mathrm{m}{ }^{-2}$

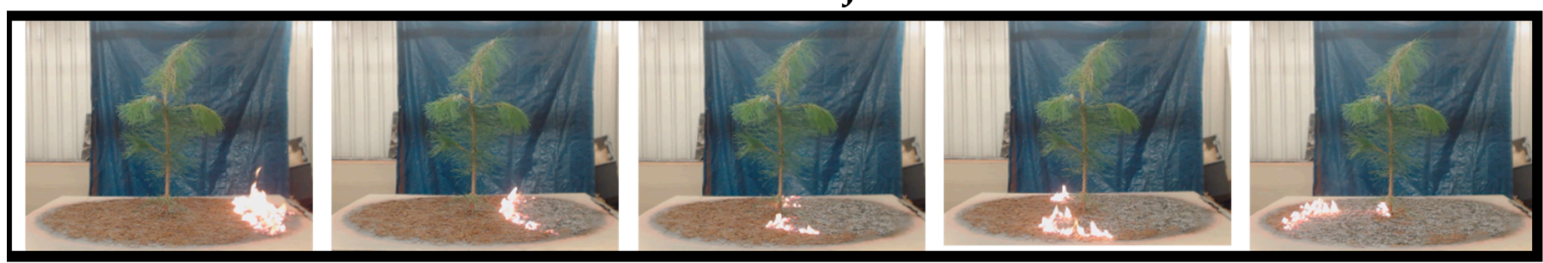

$\mathrm{FRE}=0.2 \mathrm{MJ} \mathrm{\textrm {m } ^ { - 2 }}$

Figure 1. Time-lapse video images for representative saplings undergoing surface fires of increasing fire radiative energy (FRE) dose. Greater flame length as a function of FRE dose is clearly illustrated.

This study assessed four FRE dosages incident on the plants: $0.2( \pm 0.012) \mathrm{MJ} \mathrm{m}^{-2}, 0.4( \pm 0.024) \mathrm{MJ} \mathrm{m}^{-2}$, $0.6( \pm 0.036) \mathrm{MJ} \mathrm{m}^{-2}$, and $0.8( \pm 0.048) \mathrm{MJ} \mathrm{m}^{-2}$. For each dosage $(\mathrm{L})$ that included an unburned control, ten replicates ( $r$ ) of similar-sized Pinus ponderosa saplings were used $(L=5, r=10, N=50)$. The saplings were randomly divided into each group and assigned a uniquely numbered identification tag. The $0.2 \mathrm{MJ} \mathrm{m}^{-2}, 0.4 \mathrm{MJ} \mathrm{m}^{-2}$, and $0.6 \mathrm{MJ} \mathrm{m}^{-2}$ FRE dosages were selected to re-assess inconsistent mortality results observed for other similarly sized conifer species subjected to an FRE dosage around $0.4 \mathrm{MJ} \mathrm{m}^{-2}$. Inclusion of the $0.2 \mathrm{MJ} \mathrm{m}^{-2}$ and $0.6 \mathrm{MJ} \mathrm{m}^{-2}$ dosages additionally allowed us to assess whether, as with Pinus contorta and the more recent Larix occidentalis study, the $0.4 \mathrm{MJ} \mathrm{m}^{-2}$ dosage is a LOAEL (i.e., a lowest-observed-adverse-effect-level) for mortality of Pinus ponderosa.

We based our maximum FRE dosage on data from prior studies that demonstrated near-complete mortality in similarly sized North American conifers at dosages greater than $1.0 \mathrm{MJ} \mathrm{m}^{-2}$ [4]. We also included unpublished data from a companion study that assessed mortality of similarly sized Pinus ponderosa saplings at $0.7 \mathrm{MJ} \mathrm{m}^{-2}(\mathrm{r}=5)$ and $1.0 \mathrm{MJ} \mathrm{m}^{-2}(\mathrm{r}=5)$ using identical experimental procedures. To exclude potential pseudo-replication errors, each sapling was burned individually.

\subsection{Sapling Measurements}

All saplings were marked on the bole at the root collar to allow for consistent height and stem diameter measurements from the same location. Diameter at root collar (DRC) measurements were taken with calipers on all saplings immediately prior to combustion, and once per week post-burn starting on the eleventh day after all trees were burned. Measurements continued for approximately 
four months until plant dormancy was observed. Total height measurements were taken each week with a tape measure from the same location on the stem to maintain consistency. The time lag between combustion and the initial post-burn measurements allowed the plants to equilibrate, as prior studies observed large amounts of noise in the data for up to 10 days following burns [4,8]. In all cases, the pre-fire growth characteristics (DRC, total height) were measured in each sapling $(\mathrm{cm})$ and percentage changes after the experimental burns were normalized to each individual sapling's pre-fire value. This accounted for any observed differences in diameter and height variability across all the saplings. In addition to pre-fire height and DRC, the height to live crown for each sapling was measured. At 28 days following the fire treatments, photographs were taken, and the percentage of crown volume scorched was visually estimated to the nearest $10 \%$. Representative examples of the post-fire canopy condition across all the dosages are shown in Figure 2. Following prior experiments [4,11], we assessed seedling mortality at 134 days post-fire, with the inability of meristems to regenerate shoots and complete death of the phloem and cambium beneath the bark assessed by a standard gardening cambium scratch test [33].

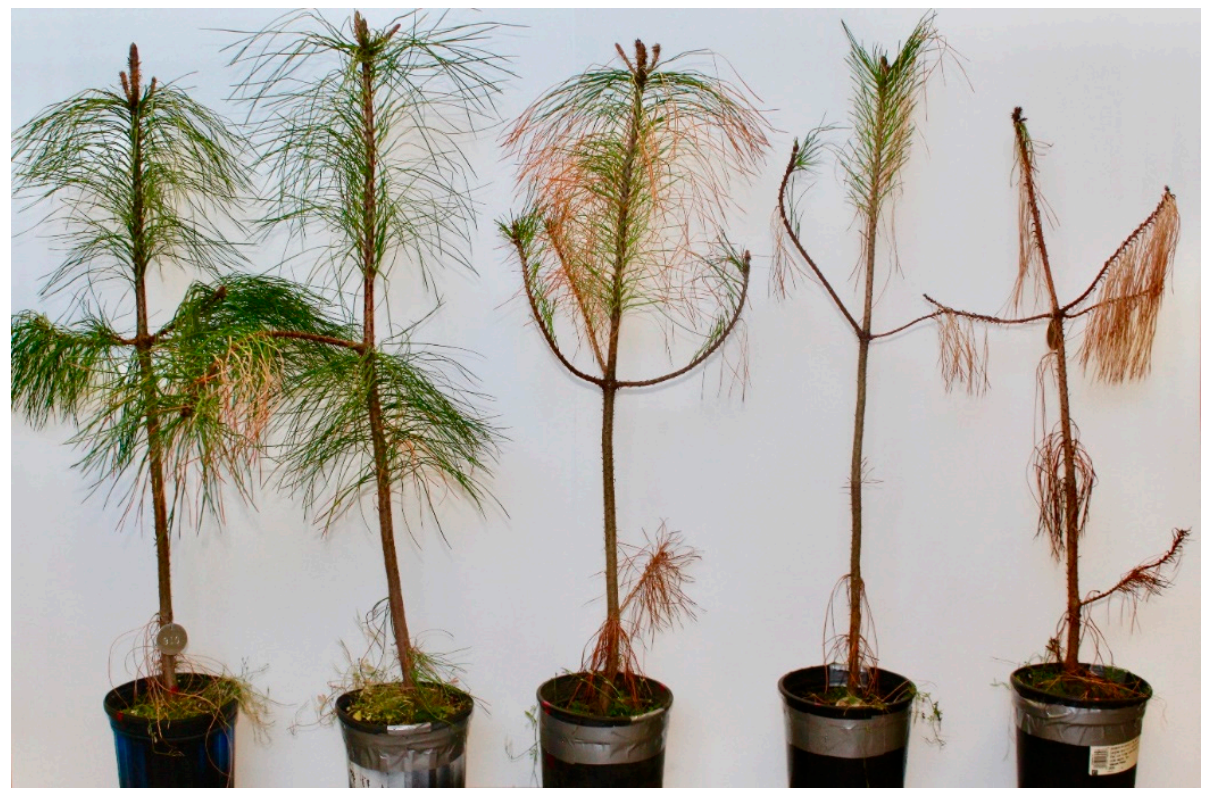

Figure 2. Representative examples of the health of the Pinus ponderosa saplings at the end of the experiment. From left to right, saplings represent the unburned control and treatments of $0.2 \mathrm{MJ} \mathrm{m}^{-2}$, $0.4 \mathrm{MJ} \mathrm{m}^{-2}, 0.6 \mathrm{MJ} \mathrm{m}^{-2}$, and $0.8 \mathrm{MJ} \mathrm{m}^{-2}$. A clear visual dose-response is apparent, with the degree of surface charring and crown scorch increasing with increasing FRE dosages.

\subsection{Comparison with Logistic Regression Models}

We identified several published logistic regressions that have been widely used to infer mortality of Pinus ponderosa $[3,6,12,28,34]$. In each case, we parameterized these equations using data collected in the current study, as the basis for a comparison with our results. Two equations that are commonly applied in fire effects modeling systems (e.g., the Forest Service Forest Vegetation Simulator [6] and the First Order Fire Effects Model [28]), are given by equations (Equation (1)) and (Equation (2)), respectively:

$$
\begin{gathered}
P_{M(\text { general })}=\frac{1}{1+\exp ^{\left(-1.941+6.316\left(1-\exp ^{-b t}\right)-0.000535 c^{2}\right)}} \\
P_{M(P I P O)}=\frac{1}{1+\exp \left(-\left(-2.7103+\left(c^{3} x 0.000004093\right)\right)\right)}
\end{gathered}
$$


where, bt (bark thickness) $=0.1803 *$ DRC $(\mathrm{cm})$ and the percentage crown volume $(\mathrm{c})$ scorched is calculated by the following equation [34]:

$$
c=100(s * 3.28) * \frac{2(l * 3.28)-(s * 3.28)}{(l * 3.28)^{2}}
$$

where, 1 is the total length of the crown $(\mathrm{m})$ and $\mathrm{s}$ is the length of the crown that is scorched (m). Tree mortality is usually assumed if $P_{M}>0.5$.

Although these equations were designed for use across all age and size classes, they were developed using larger trees $[6,28]$. Similar stem mortality logistic regressions published in the literature have been developed for deciduous and other North American tree species [23,26,35-37]. However, limited studies have explored the development of such mortality logistic regressions on young trees $[3,12,22]$. One of the few published logistic regressions focused on young Pinus ponderosa in the literature was derived by $[3,12]$ is given by (Equation (4)):

$$
P_{M(P I P O)}=\frac{1}{1+\exp (-(-2.714+(4.08 * L)+(-3.63 * H)))}
$$

where, $\mathrm{L}$ denotes flame length $(\mathrm{cm})$ and $\mathrm{H}$ denotes the sapling height $(\mathrm{cm})$ for Pinus ponderosa saplings less than $137 \mathrm{~cm}[3,12,28]$. In contrast to Equation (1) and Equation (2) which produce continuous outputs, the form of (Equation (4)) forces a binary response of either live or dead.

\subsection{Data Analysis}

Arithmetic mean \pm standard error was calculated for all results. Post-fire height and stem diameter differences between treatment groups were compared with ANOVA and, if significant $(\alpha=0.05)$, then with Tukey's honest significant difference test.

\section{Results}

Increasing FRE, which was associated with increasing flame length (Figure 1), resulted in greater crown scorch (Figure 2). Figure 3a shows the observed mortality of the Pinus ponderosa saplings at 134 days post-fire. Figure $3 \mathrm{~b}$ shows the predicted mortality curves created by applying the data collected in our study to the published logistic regressions given in eqns. 1,2 and 4. The general form of the dose-response relationship (Figure 3a) follows that observed in the prior studies on other North American conifer species $[3,4,7,8,11,12,24]$. A 'no observed adverse effect level' (NOAEL) for mortality of $0.4 \mathrm{MJ} \mathrm{m}^{-2}$ was present (i.e., no mortality was observed for each of the $0.2 \mathrm{MJ} \mathrm{m}^{-2}$ and $0.4 \mathrm{MJ} \mathrm{m}^{-2}$ dosages). In contrast, as shown in Figure 4, the NOAEL for post-fire growth was at $0.2 \mathrm{MJ} \mathrm{m}^{-2}$ as all other dosages showed a significant impact on DRC and heights. At the opposite end of the spectrum, Pinus ponderosa sapling mortality for this age class is effectively guaranteed at or exceeding dosages of $0.8 \mathrm{MJ} \mathrm{m}^{-2}$. 

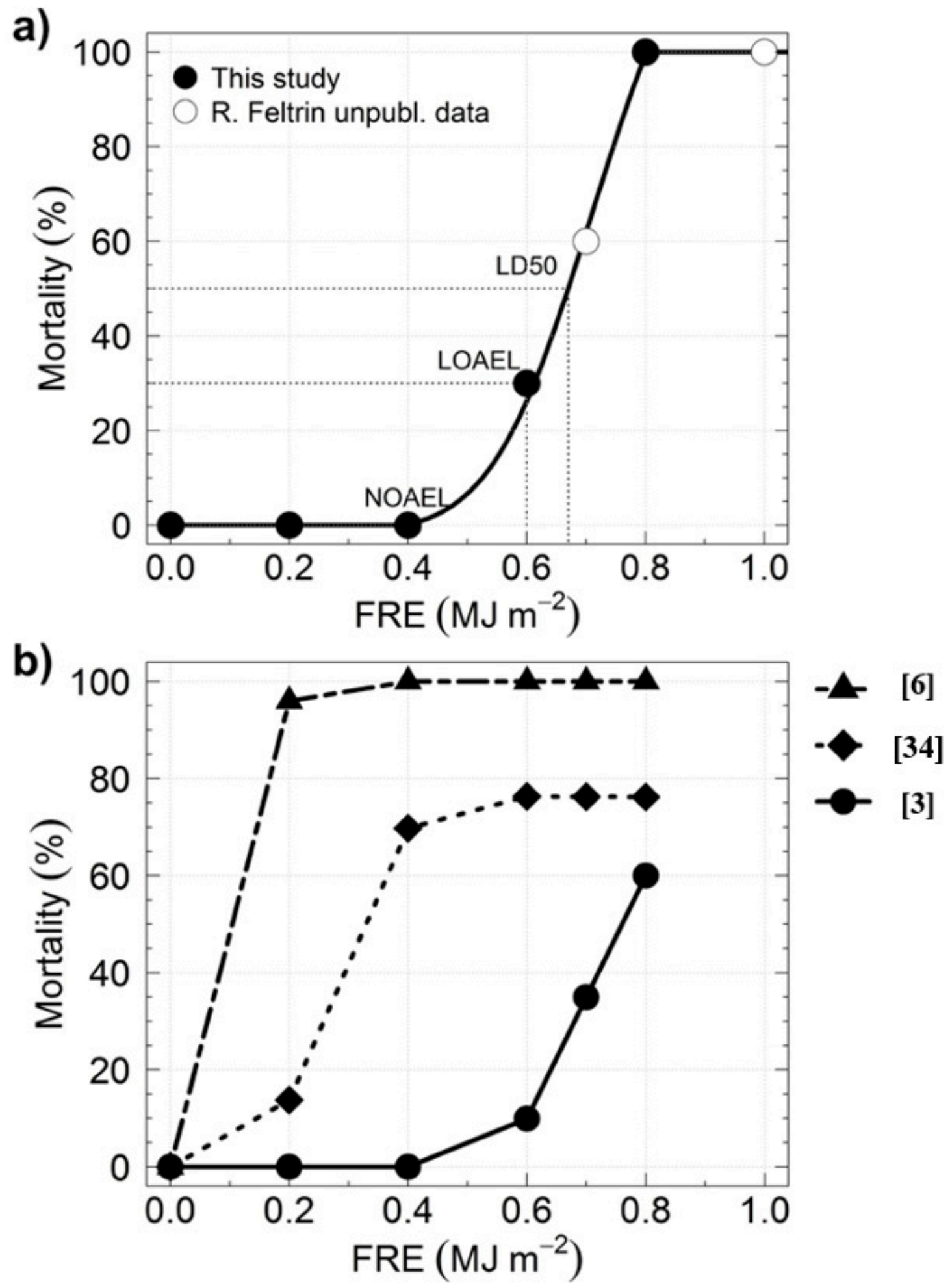

Figure 3. Mortality dose-response curve for Pinus ponderosa saplings. (a) Mortality as a function of FRE dose for 2.5-year-old Pinus ponderosa saplings in the current study. Unpublished data from a companion study (R. Feltrin unpubl. data) is also shown. (b) Equivalent dose-response curves of mortality produced using the logistic regression equations as a function of the FRE dose applied in the current study. Ancillary pre- and post-fire data collected for each sapling were used to create these dose-response curves using eqns (1-4) described in the methodology. 


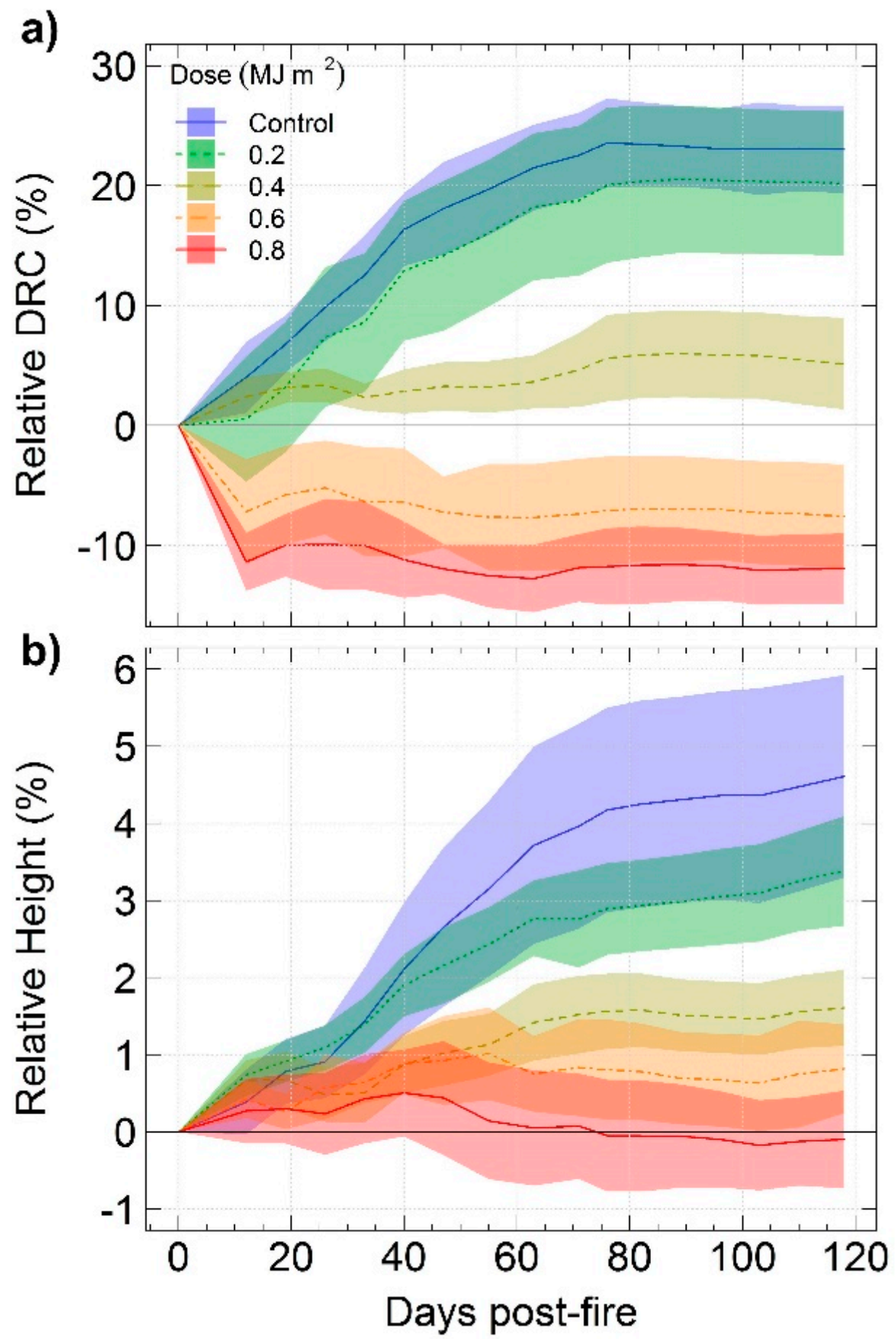

Figure 4. Relative changes in post-fire sapling growth for each treatment group $(L=5, r=10)$ for up to 120 days post-fire. (a) Relative changes in diameter at root collar (DRC). (b) Relative changes in sapling heights. The colored bands depict the $95 \%$ confidence interval for each treatment group. The lines represent the average values of the post-fire percentage changes for each group of replicates $(r=10)$, where the colored bands represent the $95 \%$ confidence interval.

Figure 4 shows the response of sapling relative DRC and height across all dosages for up to 4 months post-fire. Despite no observed mortality at the $0.4 \mathrm{MJ} \mathrm{m}^{-2}$ treatment level (Figure 3a), Figure $4 \mathrm{a}$,b clearly demonstrate, that although all these saplings were alive, they were growing at significantly reduced rates for several months after the fire. Specifically, the average stem diameter for the $0.4 \mathrm{MJ} \mathrm{m}^{-2}$ saplings at four months after the fire was $0.54 \mathrm{~cm} \pm 0.02$ as compared to $0.65 \mathrm{~cm} \pm 0.04$ 
in the control saplings. Equally, the average height for the $0.4 \mathrm{MJ} \mathrm{m}^{-2}$ at four months after the fire was $77.6 \mathrm{~cm} \pm 5.9$ as compared to $77.7 \mathrm{~cm} \pm 4.5$. In terms of absolute height growth over the 4 months post-fire, the $0.4 \mathrm{MJ} \mathrm{m}^{-2}$ averaged $1.2 \mathrm{~cm} \pm 0.2$ and the control averaged $5.1 \mathrm{~cm} \pm 1.0$.

For relative DRC (Figure 4a), there was no significant difference $(p>0.05)$ between the control and $0.2 \mathrm{MJ} \mathrm{m}^{-2}$ treatment at any point during the analysis. Relative DRC, for the $0.4 \mathrm{MJ} \mathrm{m}^{-2}, 0.6 \mathrm{MJ} \mathrm{m}^{-2}$, and $0.8 \mathrm{MJ} \mathrm{m}^{-2}$ treatment levels were all significantly lower $(p<0.001)$ than the control $\sim 33$ days post-fire. Stem shrinkage was observed in the $0.6 \mathrm{MJ} \mathrm{m}^{-2}$ and $0.8 \mathrm{MJ} \mathrm{m}^{-2}$ treatments immediately post-fire. Similarly, for relative height (Figure $4 \mathrm{~b}$ ), there was no significant difference between relative height $(p>0.05)$ between the control and $0.2 \mathrm{MJ} \mathrm{m}^{-2}$ treatment at any point during the analysis (Figure $4 \mathrm{~b}$ ). Although not significantly different, the average height value for the $0.2 \mathrm{MJ} \mathrm{m}^{-2}$ treatment was $90.7 \mathrm{~cm} \pm 4.5$ compared to $77.7 \mathrm{~cm} \pm 4.5$ for the control. Similar to DRC, the $0.4 \mathrm{MJ} \mathrm{m}^{-2}, 0.6 \mathrm{MJ} \mathrm{m}^{-2}$, and $0.8 \mathrm{MJ} \mathrm{m}^{-2}$ treatment levels were all significantly different than the control $\sim 40$ days post-fire. The loss of height observed in the $0.8 \mathrm{MJ} \mathrm{m}^{-2}$ treatment was likely due to bud shrinkage and needle loss at the top of the crown. In terms of absolute DRC growth over the 4 months post-fire, the $0.4 \mathrm{MJ} \mathrm{m}^{-2}$ averaged $0.03 \mathrm{~cm} \pm 0.01$ while the control averaged $0.12 \pm 0.01$.

\section{Discussion}

When comparing the predicted mortality curves shown in Figure $3 \mathrm{~b}$ that were created by applying the data collected in our study to the published logistic regressions of mature Pinus ponderosa given in eqns. 1 and 2, we see notable differences as compared to the experimental results shown in Figure 3a. Specifically, the logistic regressions are not sensitive to increases in FRE as they rapidly asymptote to high probabilities of tree mortality at low FRE dosages.

However, the dose-response curve produced from applying our data to the logistic regression for young Pinus ponderosa saplings (Equation (4), Figure $3 b$ ), does produce a similar curve to Figure $3 a$. A difference is apparent at the $0.8 \mathrm{MJ} \mathrm{m}^{-2}$ dosage; specifically, Equation (4) predicts only $60 \%$ mortality as compared to $100 \%$ observed in the current study. This difference was hypothesized by [4] as Pinus ponderosa saplings burned in landscape scale fires will likely be more resistant to damage from fire given their roots are not bound and they may have been hardened due to surviving other stressors (i.e., environmental hardening). However, this difference could also be due to morphological (e.g., bark thickness) or physiological differences (e.g., carbon and nutrient reserves) between field and nursery grown plants, season of burn, differences in air temperature and relative humidity, or environmental factors at the time of the planned fires. This study burned saplings in June whereas [3] used data from dormant season burns (October-February). Prior studies have observed greater mortality in mature Pinus ponderosa after growing season burns than dormant season burns despite similar levels of crown scorch $[38,39]$. In addition to season of burning, the threshold of fire behavior dosage at which mortality is certain likely increases with the age and size of the tree $[3,9,12,40]$.

The form of the dose-response curve shown in Figure 3a has the same general form as that observed for similarly sized Pinus contorta saplings [4]. An important difference that was observed between the current study and [4] was that the post-fire response data for DRC exhibited clearer separation between the dosages (Figure 4a).

These results suggest that young saplings for similar conifer species would be expected to survive planned fires with low radiative energy $\left(<0.4 \mathrm{MJ} \mathrm{m}^{-2}\right)$. Although in lesser proportions, the majority (as indicated by the 'lethal dose 50\% level', LD50 on Figure 3a) of the saplings would be expected to survive at FRE dosages less than $0.67 \mathrm{MJ} \mathrm{m}^{-2}$. However, as observed in Figure $4 \mathrm{a}, \mathrm{b}$, those that survive at this dosage will however experience significantly retarded growth. Prior research has suggested that such growth reductions may persist for several years [10], but research is needed to quantify the magnitude of this persistence to help improve growth, yield, and ecosystem models.

Although land management professionals can estimate radiant heat release from a planned fire treatment using common wildland fire combustion models (e.g., CONSUME [41], FARSITE [42]), these estimates are based on look-up tables and likely include significant errors. Future research 
needs to focus on connecting FRE with more widely accepted fire behavior metrics such as flame length, especially given the anecdotal relationship observed in Figure 1. Equally, fire science research is urgently needed to evaluate whether the percentage of energy released as radiation $(\sim 20 \%)$, as opposed to convection or conduction, is constant under landscape fire conditions, or whether the apportionment varies with fuel loading, fuel moisture, or meteorological conditions. This information will be critical to accurately parametrize models to predict FRE and subsequent post-fire effects as part of pre-fire management plan and growth and yield models that both predict tree mortality and adjust tree-growth rates in trees that survive fires. For example, the United States Forest Service Forest Vegetation Simulator Fire and Fuels Extension assumes that when the fire scorch height exceeds the base of the tree crown (common during sapling fires), the surviving trees will grow at a reduced rate for the next time step [6]. Regardless, FRE can readily measured by radiometers on towers, aerial vehicles, and satellites, which demonstrates the considerable utility of this approach on unplanned fires $[9,21,43-45]$.

\section{Conclusions}

To recap, the hypotheses we sought to test in the current study were:

(1) H1: Increased FRE (dose) leads to increased mortality (response) in Pinus ponderosa saplings up to several months post-fire.

(2) H2: Increased FRE (dose) leads to reduced growth (response) of surviving Pinus ponderosa saplings up to several months post-fire.

(3) H3: The dose-response relationships observed for Pinus ponderosa saplings are comparable to those observed for Pinus contorta [4].

(4) H4: As hypothesized by [4], the dose-response relationships observed for Pinus ponderosa saplings during laboratory fires will exhibit a higher probability of mortality at lower dose levels as compared to similar age/size saplings burnt during field experiments.

The current study supports each of these hypotheses. Specifically, we observed that increasing the FRE dosage leads to increased crown scorch, mortality and increased levels of growth retardation responses in Pinus ponderosa saplings up to several months post-fire. The overall form of the dose-response relationship is comparable to that observed for similarly aged and sized Pinus contorta and Larix occidentalis, providing more evidence that such dose-response data could be used as the basis of improved mechanistic predictive models of wildland fire severity [5,7,21]. However, the form of this relationship likely changes with increases in plant size and maturity. For example, the percentage mortality of Pinus ponderosa trees that have basal diameters of $>5 \mathrm{~cm}$ would likely decrease with increasing age because they would have started to develop thicker bark and other fire adaptive morphological characteristics [46]. Lastly, the dose-response relationship was similar to that observed in $[3,12]$, except that the laboratory-based fires exhibited higher mortality levels than the field-based models predicted at dosages exceeding $0.6 \mathrm{MJ} \mathrm{m}^{-2}$.

As described in [5,46], the development of data describing the quantity of heat incident upon saplings and trees and the development of more dose-response relationships has enormous potential to improve modeling efforts to predict post-fire tree species mortality and recovery. Such modeling efforts could include not only improved fire-effects models, but also landscape-scale models that seek to predict growth and yield of timber or carbon stock changes due to fires. Equally, FRE and other large-spatial scale radiant energy products can be coupled with large-scale climate and vegetation dynamics data to improve assessing the vulnerability of ecosystem goods and services under future fires [47-49].

Author Contributions: Conceptualization, W.D.S., R.P.F., D.M.J., C.A.K., L.B., A.S.N., A.M.S.S.; methodology, formal analysis, W.D.S., R.P.F., D.M.J., A.M.S., A.F.T., J.A.L., A.M.S.S.; writing-original draft preparation, W.D.S., R.P.F., D.M.J., A.S.K., A.F.T., J.A.L., A.M.S.S.; writing-review and editing, W.D.S., R.P.F., D.M.J., A.M.S., C.A.K., A.F.T., J.A.L., L.B., A.T.H., A.S.N., A.M.S.S. 
Funding: This project was funded by the National Science Foundation under award DMS-1520873, the National Aeronautics Space Administration under CMS-2014-3135, and the USDA McIntire-Stennis award IDAZ-MS-0117.

Conflicts of Interest: The authors declare no conflict of interest.

\section{References}

1. Schoennagel, T.; Balch, J.K.; Brenkert-Smith, H.; Dennison, P.E.; Harvey, B.J.; Krawchuk, M.A.; Mietkiewicz, N.; Morgan, P.; Moritz, M.A.; Rasker, R.; et al. Adapt to more wildfire in western North American forests as climate changes. Proc. Natl. Acad. Sci. USA 2017, 114, 4582-4590. [CrossRef] [PubMed]

2. Smith, A.M.S.; Kolden, C.A.; Bowman, D.M.J.S. Biomimicry can help humans to sustainably coexist with fire. Nat. Ecol. Evol. 2018, 2, 1827-1829. [CrossRef]

3. Battaglia, M.; Smith, F.W.; Sheppard, W.D. Predicting mortality of ponderosa pine regeneration after prescribed fire in the Black Hills, South Dakota, USA. Int. J. Wildland Fire 2009, 18, 176-190. [CrossRef]

4. Smith, A.M.S.; Talhelm, A.F.; Johnson, D.M.; Sparks, A.M.; Yedinak, K.M.; Apostol, K.G.; Tinkham, W.T.; Kolden, C.A.; Abatzoglou, J.T.; Lutz, J.A.; et al. Effects of fire radiative energy density doses on Pinus contorta and Larix occidentalis seedling physiology and mortality. Int. J. Wildland Fire 2017, 26, 82-94. [CrossRef]

5. Hood, S.M.; Varner, J.M.; van Mantgem, P.; Cansler, C.A. Fire and tree death: Understanding and improving modeling of fire induced tree mortality. Environ. Res. Lett. 2018, 13, 113004. [CrossRef]

6. Rebain, S. The Fire and Fuels Extension to the Forest Vegetation Simulator: Updated Model Documentation; Internal Rep.; U.S. Department of Agriculture, Forest Service, Forest Management Service Center: Fort Collins, CO, USA, 2015; 403p.

7. Smith, A.M.S.; Sparks, A.M.; Kolden, C.A.; Abatzoglou, J.T.; Talhelm, A.F.; Johnson, D.M.; Boschetti, L.; Lutz, J.A.; Apostol, K.G.; Yedinak, K.M.; et al. Towards a new paradigm in fire severity research using dose-response experiments. Int. J. Wildland Fire 2016, 25, 158-166. [CrossRef]

8. Sparks, A.M.; Kolden, C.A.; Talhelm, A.F.; Smith, A.M.S.; Apostol, K.G.; Johnson, D.M.; Boschetti, L. Spectral indices accurately quantify changes in tree physiology following fire: Toward mechanistic assessments of landscape post-fire carbon cycling. Remote Sens. 2016, 8, 572. [CrossRef]

9. Sparks, A.M.; Smith, A.M.S.; Talhelm, A.F.; Kolden, C.A.; Yedinak, K.M.; Johnson, D.M. Impacts of fire radiative flux on mature Pinus ponderosa growth and vulnerability to secondary mortality agents. Int. J. Wildland Fire 2017, 26, 95-106. [CrossRef]

10. Sparks, A.M.; Kolden, C.A.; Smith, A.M.S.; Boschetti, L.; Johnson, D.M.; Cochrane, M.A. Fire intensity impacts on post-fire response of temperate coniferous forest net primary productivity. Biogeosciences 2018, 15, 1173-1183. [CrossRef]

11. Sparks, A.M.; Talhelm, A.F.; Feltrin, R.P.; Smith, A.M.S.; Johnson, D.M.; Kolden, C.A.; Boschetti, L. An experimental assessment of the impact of drought and fire on western larch mortality and recovery. Int. J. Wildland Fire 2018, 27, 490-497. [CrossRef]

12. Battaglia, M.; Smith, F.W.; Sheppard, W.D. Can prescribed fire be used to maintain fuel treatment effectiveness over time in Black Hills ponderosa pine forests? For. Ecol. Manag. 2008, 256, 2029-2038. [CrossRef]

13. Lentile, L.B.; Holden, Z.; Smith, A.M.S.; Falkowski, M.J.; Hudak, A.T.; Morgan, P.; Lewis, S.A.; Gessler, P.E.; Benson, N.C. Remote sensing techniques to assess active fire and post-fire effects. Int. J. Wildland Fire 2006, 15, 319-345. [CrossRef]

14. Roy, D.P.; Boschetti, L.; Trigg, S.N. Remote sensing of fire severity: Assessing the performance of the normalized burn ratio. IEEE Geosci. Remote Sens. Lett. 2006, 3, 112-116. [CrossRef]

15. Lentile, L.B.; Morgan, P.; Hudak, A.T.; Bobbitt, M.J.; Lewis, S.A.; Smith, A.M.S.; Robichaud, P.R. Post-fire burn severity and vegetation response following eight large wildfires across the western US. Fire Ecol. 2007, 3, 91-108. [CrossRef]

16. Lentile, L.B.; Smith, A.M.S.; Hudak, A.T.; Morgan, P.; Bobbitt, M.; Lewis, S.A.; Robichaud, P. Remote sensing for prediction of 1-year post-fire ecosystem condition. Int. J. Wildland Fire 2009, 18, 594-608. [CrossRef]

17. Hudak, A.T.; Morgan, P.; Bobbitt, M.J.; Smith, A.M.S.; Lewis, S.A.; Lentile, L.B.; Robichaud, P.R.; Clark, J.T.; McKinley, R.A. The relationship of multispectral satellite imagery to immediate fire effects. Fire Ecol. 2007, 3, 64-90. [CrossRef]

18. Kolden, C.A.; Smith, A.M.S.; Abatzoglou, J.T. Limitations and utilization of Monitoring Trends in Burn Severity products for assessing wildfire severity in the USA. Int. J. Wildland Fire 2015, 24, 1023-1028. [CrossRef] 
19. McCarley, T.R.; Smith, A.M.S.; Kolden, C.A.; Kreitler, J. Evaluating the mid-infrared bi-spectral index for assessing severity and area burned in a conifer forest. Int. J. Wildland Fire 2018, 27, 407-412. [CrossRef]

20. McCarley, T.R.; Kolden, C.A.; Vaillant, N.M.; Hudak, A.T.; Smith, A.M.S.; Wing, B.M.; Kellogg, B.; Kreitler, J. Multi-temporal LiDAR and Landsat quantification of fire induced changes to forest structure. Remote Sens. Environ. 2017, 191, 419-432. [CrossRef]

21. Jolly, W.M.; Johnson, D.M. Pyro-Ecophysiology: Shifting the Paradigm of Live Wildland Fuel Research. Fire 2018, 1, 8. [CrossRef]

22. Huddle, J.A.; Pallardy, S.G. Effects of soil and stem base heating on survival, resprouting and gas exchange of Acer and Quercus seedlings. Tree Physiol. 1996, 16, 583-589. [CrossRef]

23. Furniss, T.J.; Larson, A.J.; Kane, V.R.; Lutz, J.A. Multi-scale assessment of post-fire tree mortality models. Int. J. Wildland Fire 2019, 28, 46-61. [CrossRef]

24. Ryan, K.C.; Reinhardt, E.D. Predicting postfire mortality of seven western conifers. Can. J. For. Res 1988, 18, 1291-1297. [CrossRef]

25. Kobziar, L.; Moghaddas, J.; Stephens, S.L. Tree mortality patterns following prescribed fires in a mixed conifer forest. Can. J. For. Res. 2006, 36, 3222-3238. [CrossRef]

26. Woolley, T.; Shaw, D.C.; Ganio, L.M.; Fitzgerald, S. A review of logistic regression models used to predict post-fire tree mortality of western North American conifers. Int. J. Wildland Fire 2012, 21, 1-35. [CrossRef]

27. Hood, S.M.; McHugh, C.W.; Ryan, K.C.; Reinhardt, E.; Smith, S.L. Evaluation of a post-fire tree mortality model for western USA conifers. Int. J. Wildland Fire 2007, 16, 679-689. [CrossRef]

28. Lutes, D. FOFEM 6.5 First Order Fire Effects Model User Guide, Fire and Aviation Management. Rocky Mountain Research Station Fire Modelling Institute, United States Department of Agriculture, 2018. Available online: https://www.firelab.org/document/fofem-files (accessed on 19 March 2019).

29. Dietrich, J.H. Recovery Potential of Fire-Damaged Southwestern Ponderosa Pine. Rocky Mountain Forest and Range Experiment Station; Research Note-379; U.S. Department of Agriculture, Forest Service: Ogden, UT, USA, 1979.

30. Dumroese, D.S.; Abbott, A.M.; Rice, T.M. Forest Soil Disturbance Monitoring Protocol-II; Gen. Tech. Rep. WO-GTR-82b; U.S. Department of Agriculture, Forest Service: Washington, DC, USA, 2009; 64p.

31. Smith, A.M.S.; Tinkham, W.T.; Roy, D.P.; Boschetti, L.; Kumar, S.; Sparks, A.M.; Kremens, R.L.; Falkowski, M.J. Quantification of fuel moisture effects on biomass consumed derived from fire radiative energy retrievals. Geophys. Res. Lett. 2013, 40, 6298-6302. [CrossRef]

32. Matthews, S. Effect of drying temperature on fuel moisture content measurements. Int. J. Wildland Fire 2010, 19, 800-802. [CrossRef]

33. Mercker, D.C.; Buckley, D.S.; Conn, J.P. Effects of prolonged storage on survival and growth of outplanted bottomland oaks. In Proceedings of the 17th Central Hardwood Forest Conference, Lexington, KY, USA, 5-7 April 2010; Gen. Tech. Rep. NRS-P-78. Fei, S., Lhotka, J.M., Stringer, J.W., Gottschalk, K.W., Miller, G.W., Eds.; U.S. Department of Agriculture, Forest Service, Northern Research Station: Newtown Square, PA, USA, 2011; pp. 341-346.

34. Hood, S.; Lutes, D. Predicting post-fire tree mortality for 12 western US conifers using the first order fire effects model (FOFEM). Fire Ecol. 2017, 13, 66-84. [CrossRef]

35. Peterson, D.L. and Ryan, K.C. Modeling Postfire Conifer Mortality for Long-range Planning. Environ. Manag. 1986, 10, 797-808. [CrossRef]

36. Brown, J.K.; DeByle, N.V. Fire damage, mortality, and suckering in aspen. Can. J. For. Res. 1987, 17, 1100-1109. [CrossRef]

37. Keyser, T.L.; McDaniel, V.L.; Klein, R.N.; Drees, D.G.; Burton, J.A.; Forder, M.M. Short-term stem mortality of 10 deciduous broadleaved species following prescribed burning in upland forests of the Southern US. Int. J. Wildland Fire 2018, 27, 42-51. [CrossRef]

38. Harrington, M.G. Ponderosa pine mortality from spring, summer, and fall crown scorching. West. J. Appl. For. 1987, 2, 14-16.

39. Harrington, M.G. Predicting Pinus ponderosa mortality from dormant season and growing-season fire injury. Int. J. Wildland Fire 1993, 3, 65-72. [CrossRef]

40. McDowell, N.G.; Michaletz, S.T.; Bennett, K.E.; Solander, K.C.; Xu, C.; Maxwell, R.M.; Middleton, R.S. Predicting chronic climate-driven disturbances and their mitigation. Trends Ecol. Evol. 2018, 33, 15-27. [CrossRef] 
41. Ottmar, R.D.; Burns, M.F.; Hall, J.N.; Hanson, A.D. CONSUME: Users Guide; Gen. Tech. Rep. PNW-GTR-304; U.S. Department of Agriculture, Forest Service, Pacific Northwest Research Station: Portland, OR, USA, 1993; pp. 1-133.

42. Finney, M.A. FARSITE: Fire Area Simulator-Model Development and Evaluation; Gen. Tech. Rep. RMRS-RP-4; U.S. Department of Agriculture, Forest Service, Rocky Mountain Research Station: Ogdon, UT, USA, 2004; pp. 1-47.

43. Kremens, R.; Smith, A.M.S.; Dickinson, M. Fire Metrology: Current and future directions in physics-based measurements. Fire Ecol. 2010, 6, 13-35. [CrossRef]

44. Wooster, M.J.; Roberts, G.; Perry, G.L.W.; Kaufman, Y.J. Retrieval of biomass combustion rates and totals from fire radiative power observations: FRP derivation and calibration relationships between biomass consumption and fire radiative energy release. J. Geophys. Res. 2005, 110, 1-24. [CrossRef]

45. Roberts, G.; Wooster, M.J.; Perry, G.L.W.; Drake, N.; Rebelo, L.M.; Dipotso, F. Retrieval of biomass combustion rates and totals from fire radiative power observations: Application to southern Africa using geostationary SEVIRI imagery. J. Geophys. Res. 2005, 110, 1-19. [CrossRef]

46. Fitzgerald, S. Fire ecology of ponderosa pine and the rebuilding of fire-resilient ponderosa pine ecosystems. In Proceedings of the Symposium on Ponderosa Pine: Issues, Trends, and Management, Klamath Falls, OR, USA, 18-21 October 2004; Gen. Tech. Rep PSW-GTR-198. Ritchie, M.W., Maguire, D.A., Youngblood, A., Eds.; U.S. Department of Agriculture, Forest Service, Pacific Southwest Research Station: Albany, CA, USA, 2004; pp. 197-228.

47. Dickinson, M.B.; Butler, B.W.; Hudak, A.T.; Bright, B.C.; Kremens, R.L.; Klauberg, C. Inferring energy incident on sensors in low-intensity surface fires from remotely sensed radiation and using it to predict tree stem injury. Int. J. Wildland Fire 2019, 28, 230-236. [CrossRef]

48. Smith, A.M.S.; Kolden, C.A.; Tinkham, W.T.; Talhelm, A.; Marshall, J.D.; Hudak, A.T.; Boschetti, L.; Falkowski, M.J.; Greenberg, J.A.; Anderson, J.W.; et al. Remote Sensing the Vulnerability of Vegetation in Natural Terrestrial Ecosystems. Remote Sens. Environ. 2014, 154, 322-337. [CrossRef]

49. Bowman, D.M.J.S.; Williamson, G.; Kolden, C.A.; Abatzoglou, J.T.; Cochrane, M.A.; Smith, A.M.S. Human exposure and sensitivity to globally extreme wildfire events. Nat. Ecol. Evol. 2017, 1, 0058. [CrossRef] [PubMed]

(C) 2019 by the authors. Licensee MDPI, Basel, Switzerland. This article is an open access article distributed under the terms and conditions of the Creative Commons Attribution (CC BY) license (http://creativecommons.org/licenses/by/4.0/). 